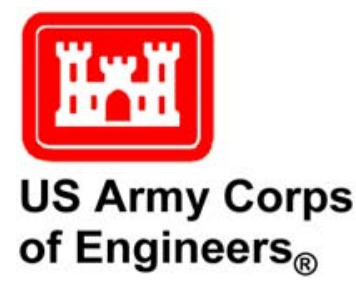

\title{
Influence of Marsh Restoration and Degradation on Storm Surge and Waves
}

\author{
by Ty V. Wamsley, Mary A. Cialone, Joannes Westerink, \\ and Jane M. Smith
}

PURPOSE: The purpose of this CHETN is to examine storm surge and wave reduction benefits of marsh restoration, as well as the impact of future wetland degradation on local surge and wave conditions. Storm surge simulations of representative moderate and severe hurricanes were performed using the ADCIRC storm surge model, with the inclusion of radiation stress gradients from the STWAVE nearshore wave model. Coupled model simulations were made for wetland landscape configurations in south Louisiana that involved hypothetical restored and degraded wetland features. This is the first in a series of tech notes on the influence of marshes on storm surge and waves.

INTRODUCTION: Coastal areas are vulnerable to devastating storm surge and waves, a vulnerability that will increase with the ever-increasing population that seeks to reside along the coast and its accompanying infrastructure. The threat will be exacerbated by any increase in the frequency and severity of hurricanes as well as an increase in relative sea level. Topography, landscape features, and vegetation have the potential to reduce storm surge elevations and absorb wave energy. Land elevations greater than the storm surge elevation act as a physical barrier and create bathymetric resistance for the surge and waves. Landscape features such as wetlands also have the potential to create frictional resistance and affect storm surge and wave energy even if submerged. The purpose of this study is to apply numerical models to assess the potential of coastal landscape features for reducing storm surge and waves for hurricanes with varying intensity. The analysis provides valuable information on trends and relative performance but should not be taken as an absolute quantitative assessment of surge and wave reduction.

MODELING SYSTEM: A team of engineers and scientists specializing in coastal hydrodynamics, meteorology, statistics, and computer science collaborated to develop an integrated modeling system to estimate storm surge inundation. A schematic diagram of the system is shown in Figure 1. The modeling system was validated for Hurricanes Katrina and Rita (see Bunya et al. 2009) and was shown to be accurate within $+/-0.5 \mathrm{~m}$ of the measured high water marks. These storms were selected due to the unprecedented quality of the storm system data and resulting high water marks. In addition, the extent of inland inundation was extreme, allowing for a unique opportunity to validate the effectiveness of numerical models that include variation in topography, overland resistance, and overland wind speeds.

For each storm, defined by a track and time-varying wind field parameters, the TC96 Planetary Boundary Layer (PBL) model (Thompson and Cardone 1996) was applied to construct snapshots of wind and atmospheric pressure fields every 15 minutes for driving surge and wave models. ADCIRC (Luettich et al. 1992, Westerink et al. 1994, Luettich and Westerink 2004) was then run to compute the pressure- and wind-driven surge component. In parallel with the initial ADCIRC runs, the large-domain, discrete, time-dependent spectral wave model WAM (Komen 
et al. 1994) was run to calculate directional wave spectra that serve as boundary conditions for the local-domain, near-coast wave model STWAVE (Smith et al. 2001, Smith 2007). Using initial water levels from ADCIRC, winds that include the effects of sheltering due to land boundaries and reduction due to land roughness, and spectral boundary conditions from WAM, STWAVE was run to produce wave fields and estimated radiation stress fields. The radiation stress fields were added to the estimated wind stresses, and the ADCIRC model was run again for the time period during which the radiation stresses potentially make a significant contribution to the water levels.

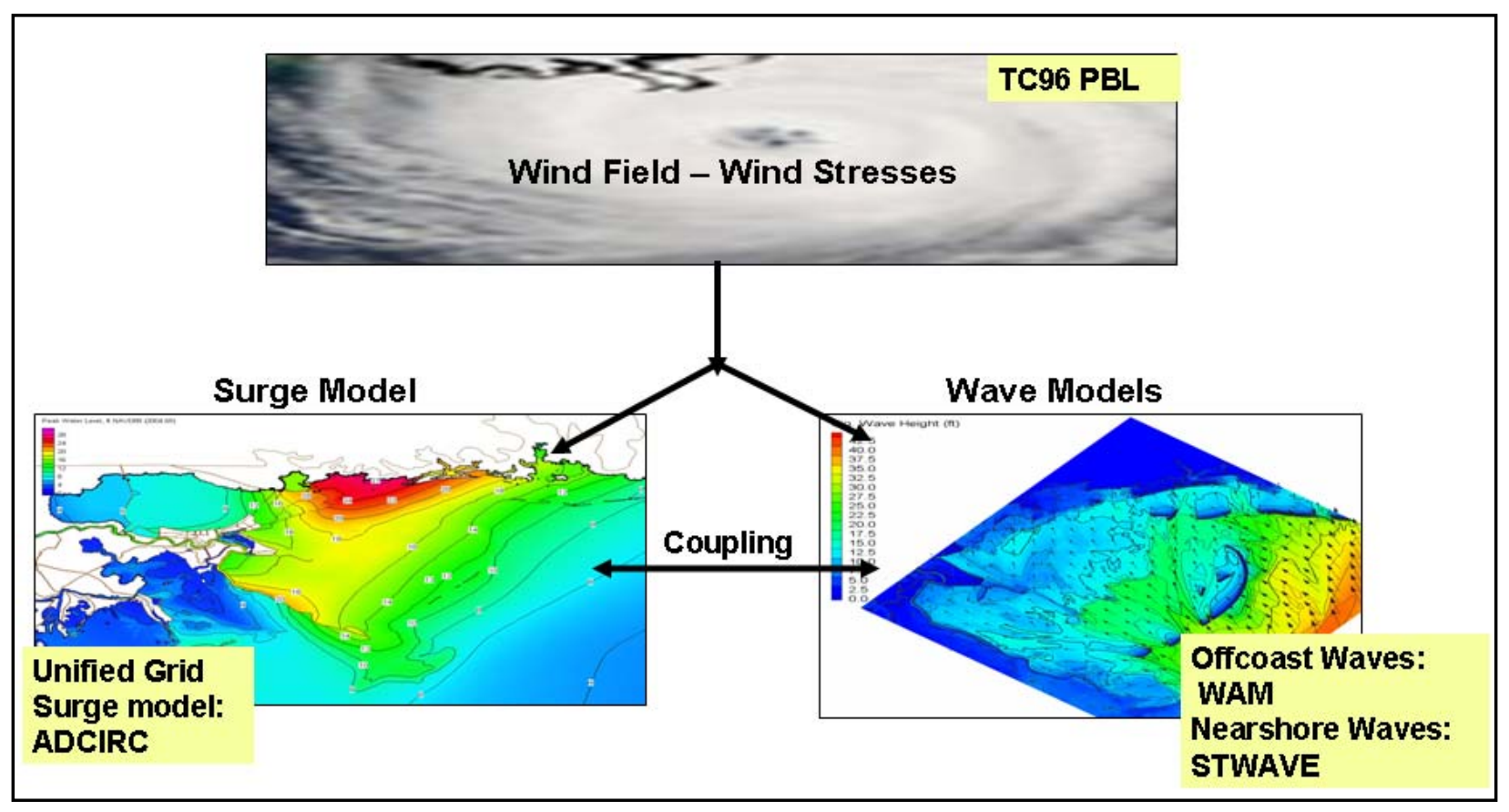

Figure 1. Diagram of modeling system for coastal inundation application.

MODEL SETUP: The modeling system was applied to perform a sensitivity analysis to assess the impact of wetland restoration and degradation on hurricane surge and waves. Simulations were made for landscape configurations in south Louisiana that involved a base condition and hypothetical restored and degraded conditions for Caernarvon marsh. The base configuration was consistent with the existing post-Hurricane Katrina condition in south Louisiana. For the degraded condition, the marsh area outlined in Figure 2 was lowered to $0.6 \mathrm{~m}$ below North Atlantic Vertical Datum 1988 (NAVD88) to represent an estimate of the long-term effects of subsidence and degradation and characterized as open water. The improved marsh was raised to approximately +0.3 m NAVD88 and characterized as intermediate marsh.

Two storms were simulated for each configuration giving a total of six simulations. The first storm (HUR1) was a large hurricane of moderate intensity with a central pressure of approximately $960 \mathrm{mb}$, a radius to maximum winds of $39 \mathrm{~km}$, and a forward speed of $20 \mathrm{~km} / \mathrm{hr}$. HUR1 parameters are similar to Hurricane Hilda, which made landfall in south central Louisiana in 1964. The second storm (HUR2) was a large hurricane of severe intensity with a central pressure of approximately $900 \mathrm{mb}$, a radius to maximum winds of $39 \mathrm{~km}$, and a forward speed of $20 \mathrm{~km} / \mathrm{hr}$. These parameters are similar to Hurricane Katrina in 2005. Both storms followed a 
track oriented primarily south to north through the Biloxi marsh. The track path is plotted in the base condition result figures (see Figure 3 for example).

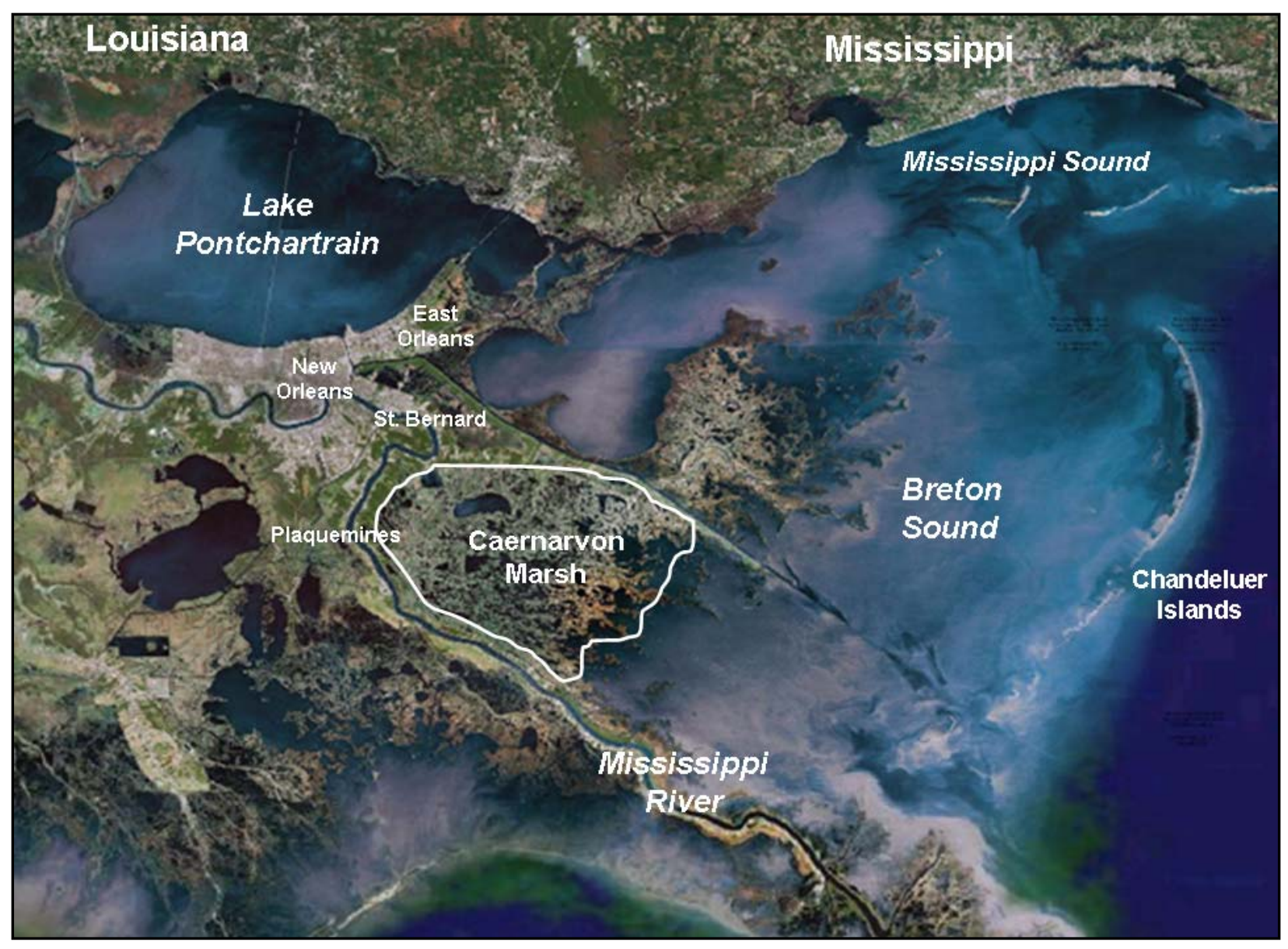

Figure 2. Study area.

The landscape degradation and restoration were represented in the numerical models by bathymetric and frictional resistance changes. The base condition coastal feature landscape land cover type was taken from the United States Geological Survey (USGS) National Land Cover Dataset (NLCD) classification raster map based upon Landsat imagery and the USGS Landsat Data Gap study. Each NLCD/Gap classification had an associated land roughness length $\left(\mathrm{z}_{\text {oland }}\right)$ and Manning $n$ value (see Westerink et al. 2008 and Wamsley et al. 2009). The roughness length values were obtained from the Federal Emergency Management Agency (FEMA) Hazards U.S. (HAZUS) study and are defined as the height where the wind speed becomes zero using a logarithmic wind profile. The final Manning $n$ values were determined through the hindcasts of hurricanes Rita and Katrina. All Manning $n$ values were within the expected range of values for their land-use categories according to standard hydraulic texts. The roughness length and Manning $n$ values used for the Caernarvon marsh analysis are representative of an intermediate marsh with $z_{\text {Oland }}=0.11 \mathrm{~m}$ and Manning $n=0.04$. 


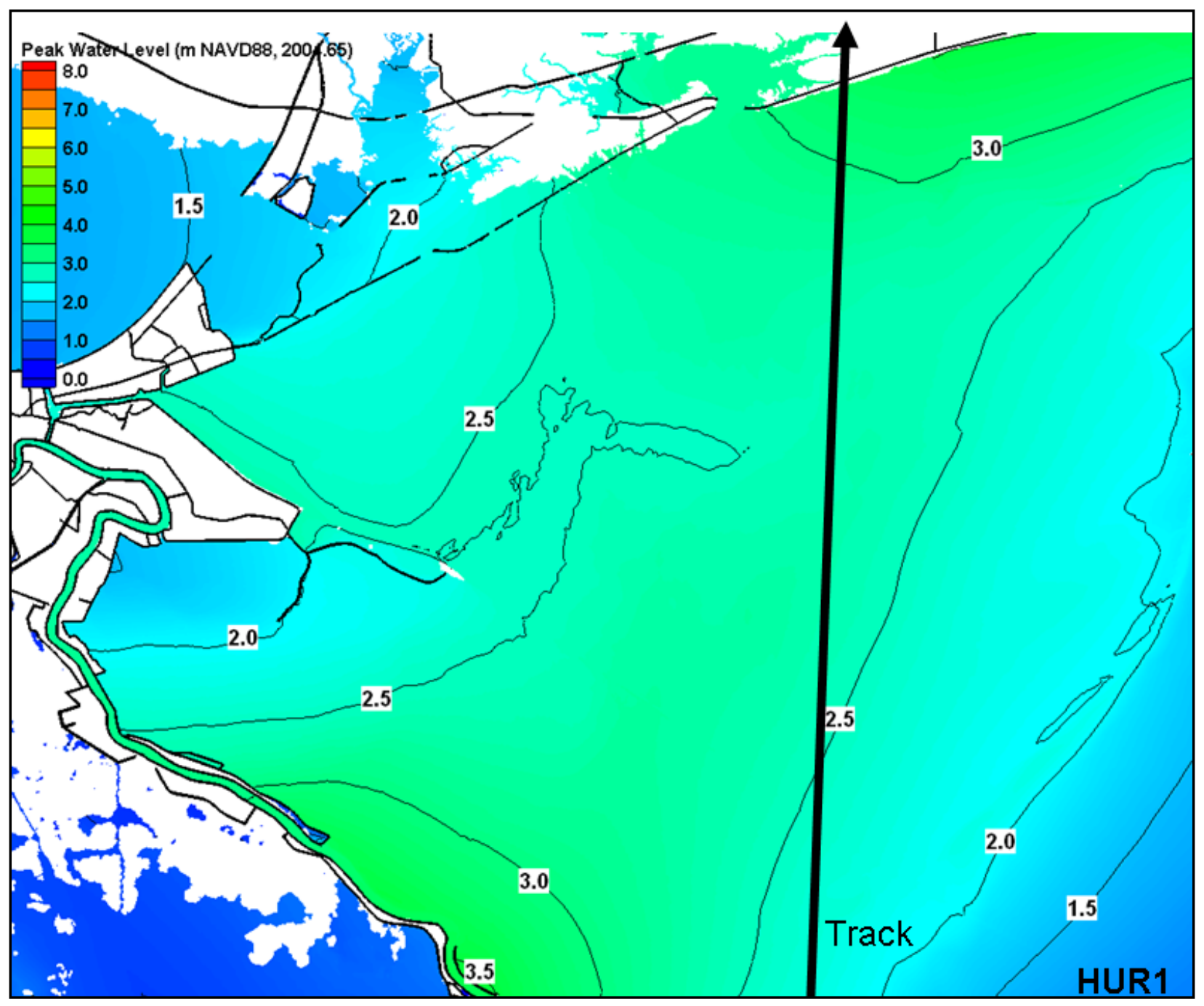

Figure 3. Peak surge level for HUR1, Base condition.

The winds input to the ADCIRC and STWAVE models were reduced to account for the higher surface roughness through a directional land masking procedure. Briefly, the land masking procedure incorporates the distance for the wind boundary layer to adjust to the surface roughness. To represent this phenomenon in the models, wind reduction factors were computed based on the weighted average of roughness coefficients $\left(z_{\text {oland }}\right)$ within $10 \mathrm{~km}$ in the upwind direction employing an inverse distance weighting function (see Westerink et al. 2008 and Wamsley et al. 2009).

The speed at which a storm surge propagates (and the resulting water elevation) is affected by coastal landscape features through bottom friction and form drag. Bottom friction is generated by fluid shear stresses at the seabed and flow-drag resistance is generated by fluid stresses on objects extending through the water column. Bottom friction occurs in relatively shallow areas and bottom friction and flow-drag resistance can occur in vegetated areas. The ADCIRC and STWAVE models presently only account for bottom friction, and therefore the effect of form drag can only be approximated by increasing the bottom friction coefficient. The ADCIRC and STWAVE models apply a Manning's-type bottom friction formulation. 
RESULTS: Storm surge and wave reduction benefits of marsh restoration and degradation on local surge and wave conditions were examined by comparing peak water level and significant wave height maps for each of the altered Caernarvon marsh configurations to the base condition for both storms HUR1 and HUR2. The analysis focused on changes in water level and waves at the hurricane protection system along the east and south facing levees in the Plaquemines and St. Bernard Parishes (see Figure 2). As would be expected, restoration and degradation of marsh resulted in decreases (for restoration cases) and increases (for degradation cases) in both surge and wave magnitudes at the hurricane protection system. In general, the wave change patterns are consistent with the water level changes. The waves may be controlled by increased frictional resistance in the shallower water, non-local depth-limited breaking (e.g., at the edge of the marsh), or be depth-limited at the marsh.

Base Condition. Figures 3-6 are the peak water level and wave height maps for storms HUR1 and HUR2. The maximum offshore wave heights are $11 \mathrm{~m}$ and $16 \mathrm{~m}$ for HUR1 and HUR2, respectively. Maximum surges for HUR1 in the pocket between the south St. Bernard and Plaquemines levees (Caernarvon pocket) are 2 to $2.5 \mathrm{~m}$ and maximum wave heights are less than $0.5 \mathrm{~m}$. Surges and wave heights increase for HUR2 with peak water levels of 2.5 to $5 \mathrm{~m}$ and maximum wave heights are greater than HUR 1, but still generally less than $0.5 \mathrm{~m}$.

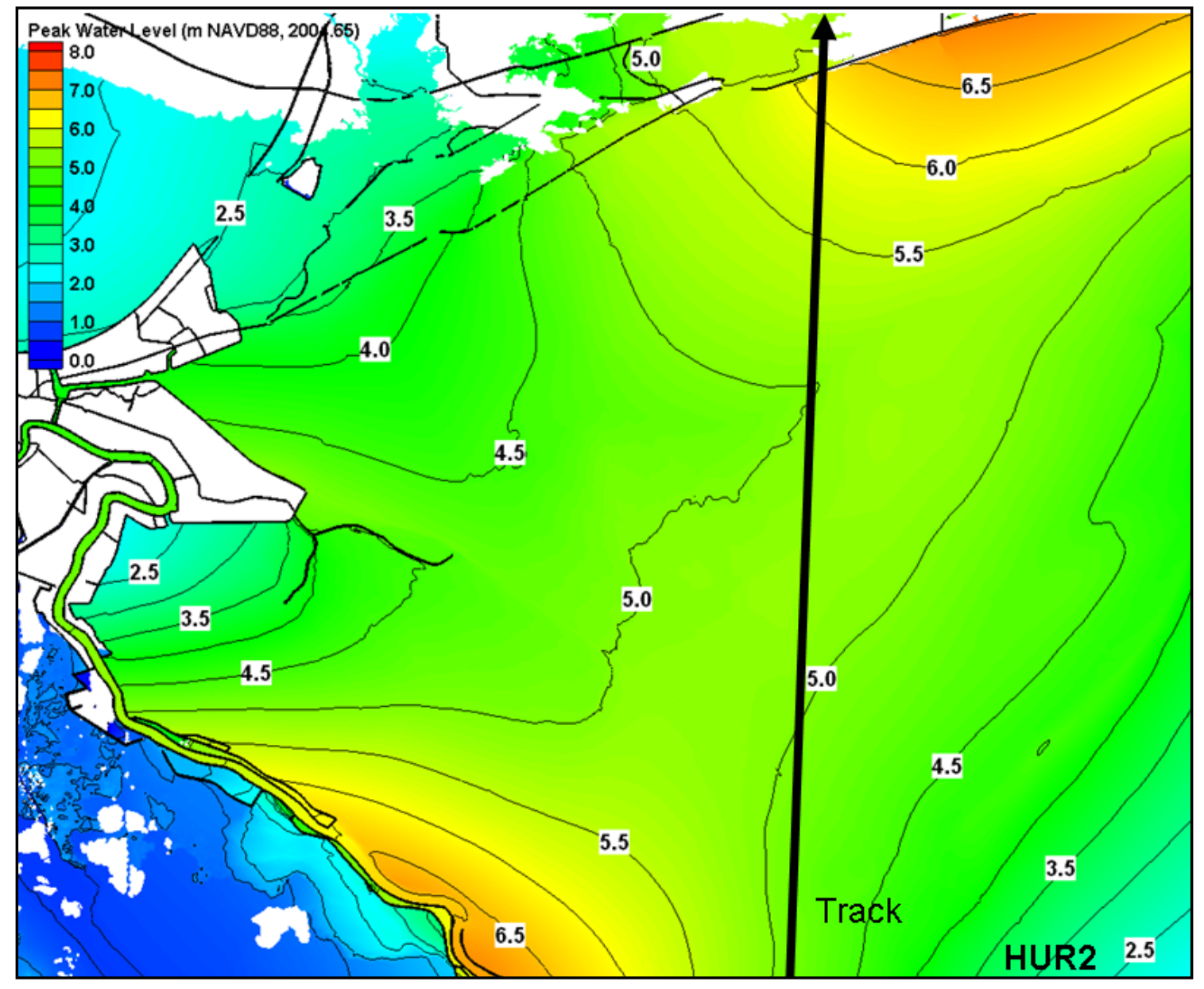

Figure 4. Peak surge level for HUR2, Base condition. 
ERDC/CHL CHETN-I-77

July 2009

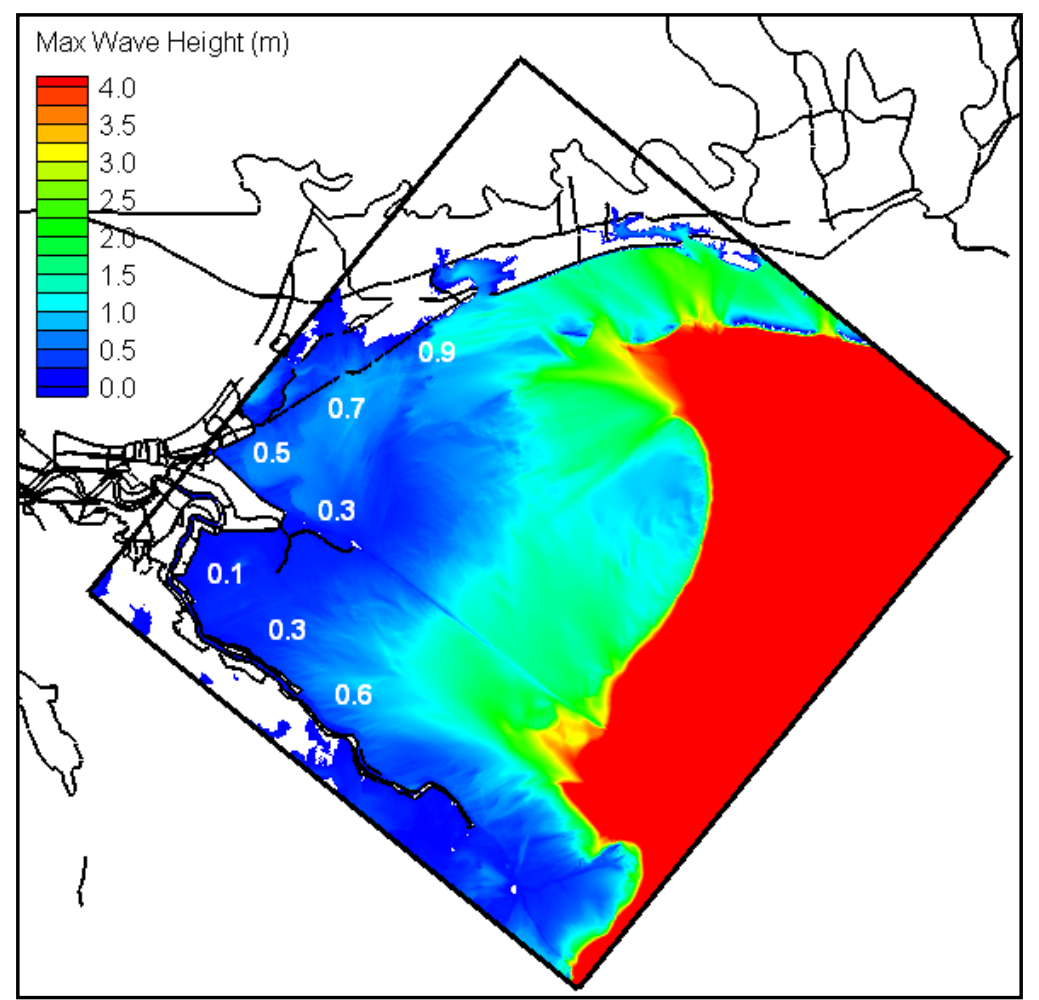

Figure 5. Maximum wave heights for HUR1, Base condition.

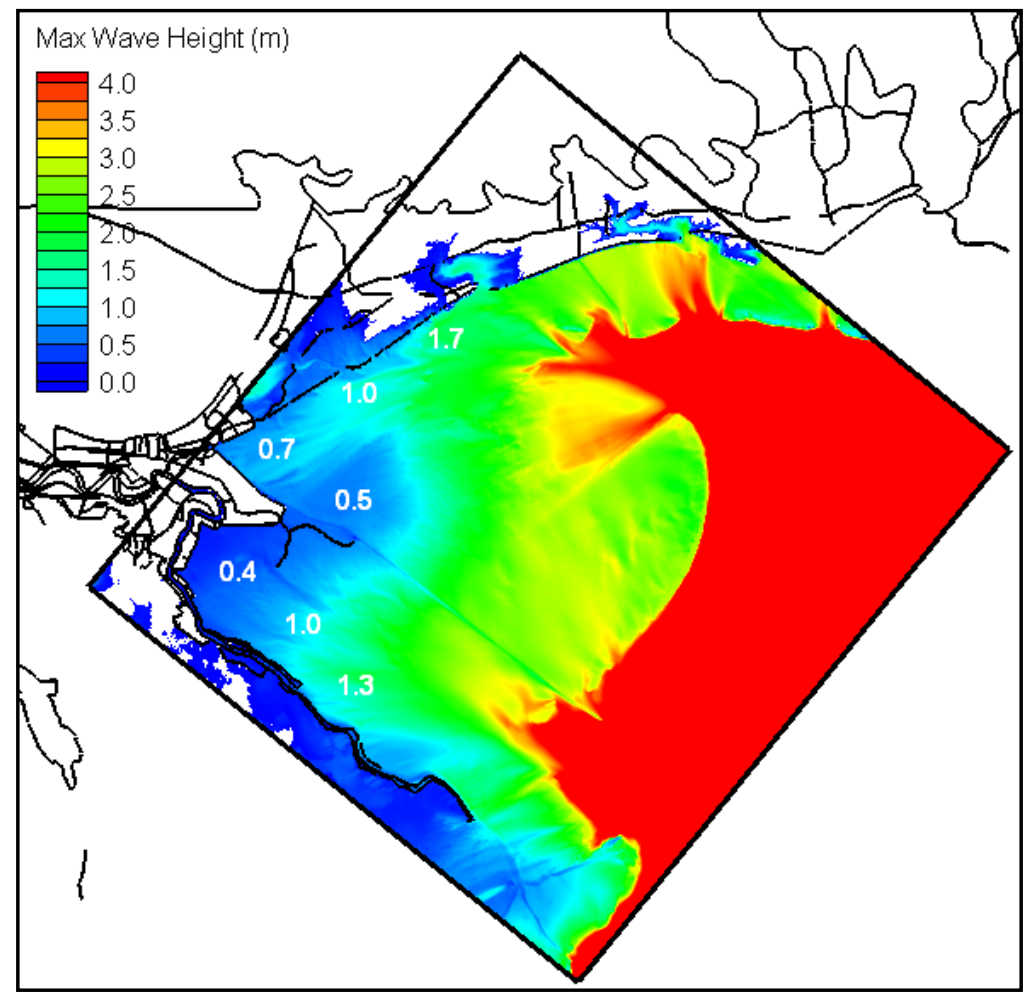

Figure 6. Maximum wave heights for HUR2, Base condition. 
Caernarvon Marsh. Figures 7-8 plot the difference between the Caernarvon marsh restoration and base condition peak water levels and maximum wave heights for both HUR1 and HUR2. The impact of restoration of the entire Caernarvon marsh was generally limited to the Caernarvon area for both HUR1 and HUR2. The change in bathymetry and frictional resistance slowed surge propagation resulting in an increase in water level seaward of the changes and a decrease in water level landward. Maximum surge elevation was reduced less than $0.5 \mathrm{~m}$ along the south St. Bernard levee and between 0.5 and $1 \mathrm{~m}$ along the Plaquemines levees for both storms. Maximum wave heights were reduced by less than $0.5 \mathrm{~m}$.

Figures 9-10 plot the difference between the Caernarvon marsh degradation and base condition peak water levels and maximum wave heights for both HUR1 and HUR2. The marsh degradation allowed surge to propagate more rapidly, resulting in a rise in peak water level relative to the base condition for both storms. For HUR1, peak water levels increased 0.5 to $1.5 \mathrm{~m}$ for HUR1 and by as much as about $2 \mathrm{~m}$ for HUR2. Maximum wave heights along the levees in the Caernarvon pocket area increased as much as about $1 \mathrm{~m}$ for both HUR1 and HUR2.

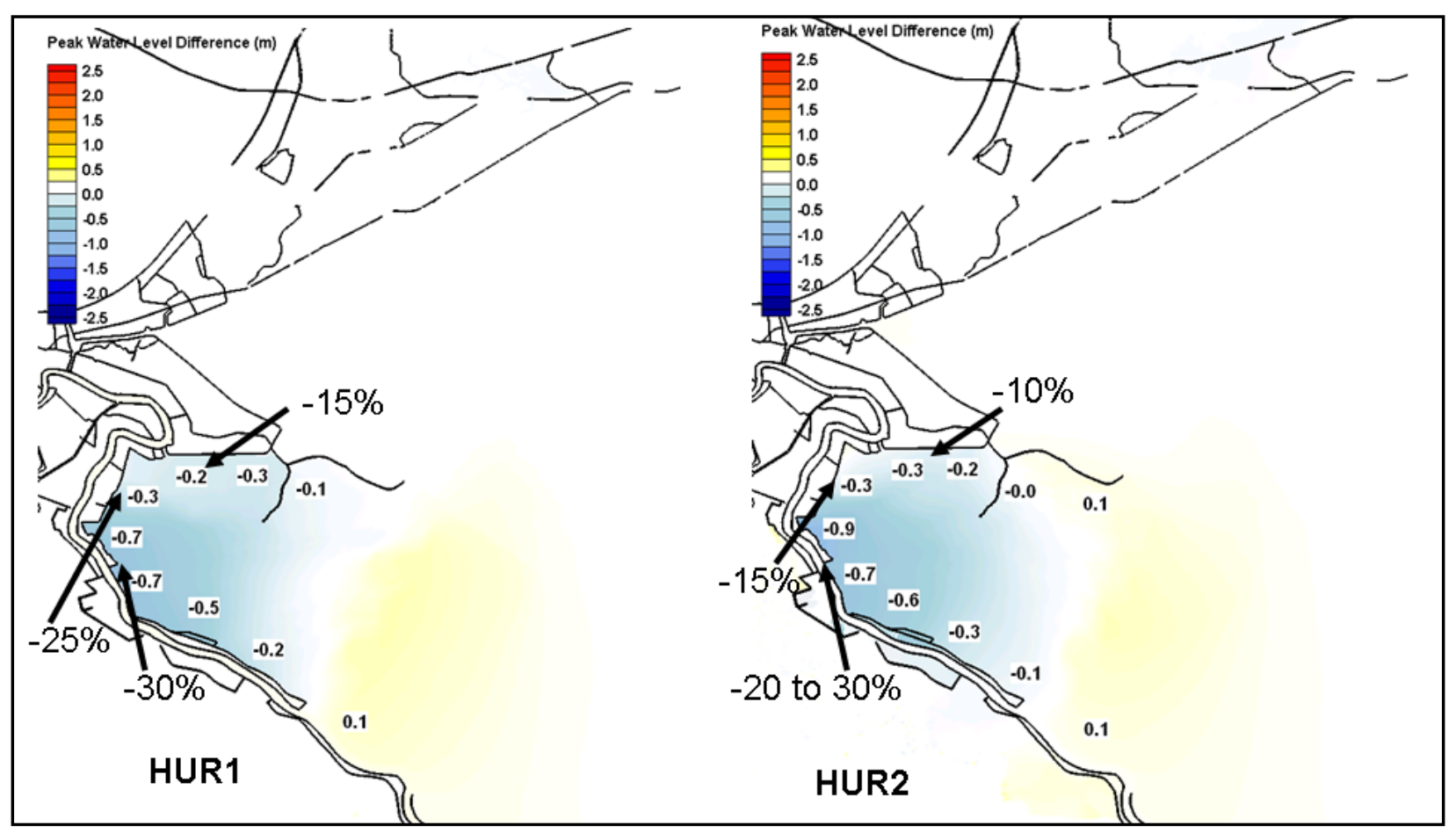

Figure 7. Difference in peak surge level between the restored and base conditions. 


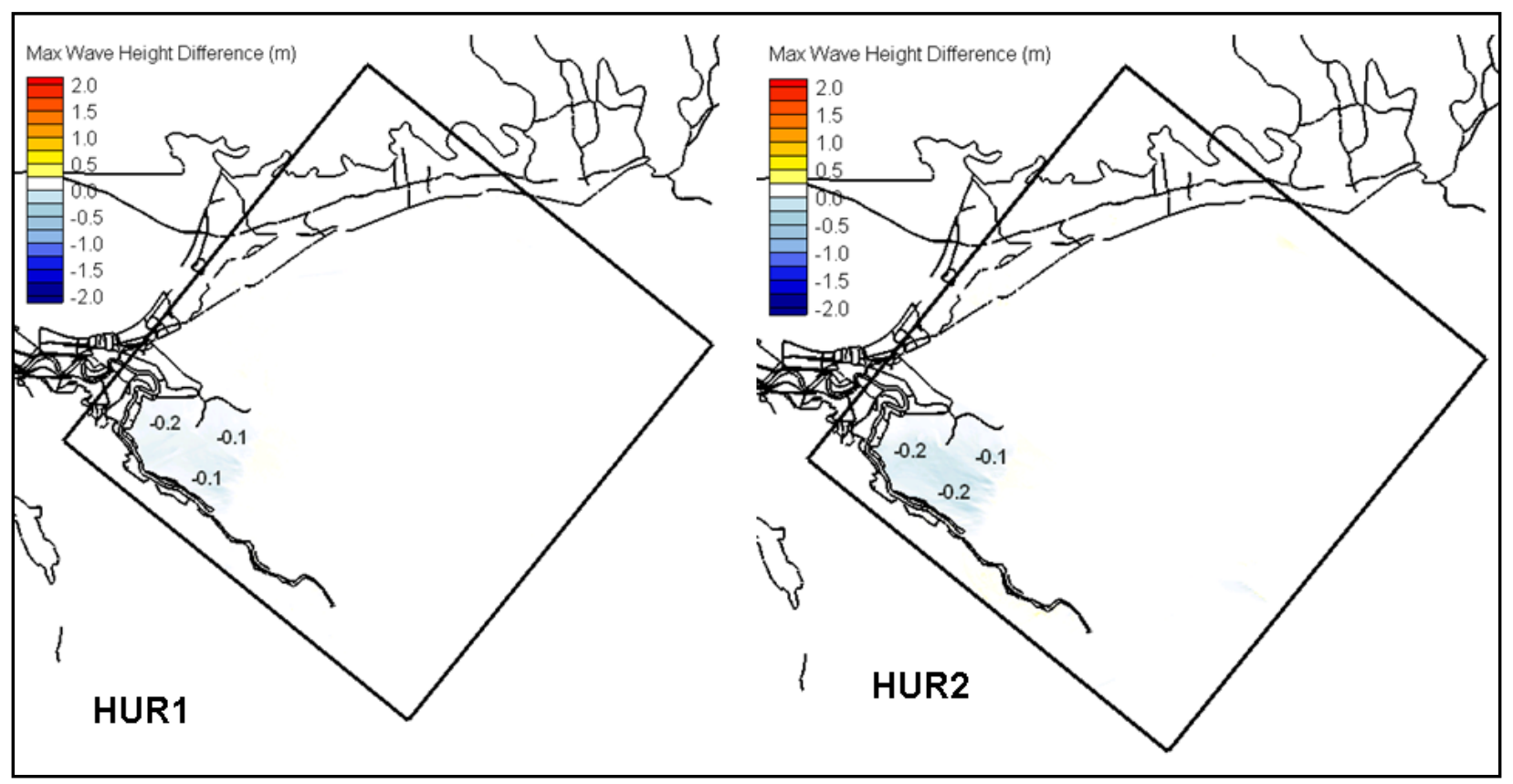

Figure 8. Difference in maximum wave height between the restored and base conditions.

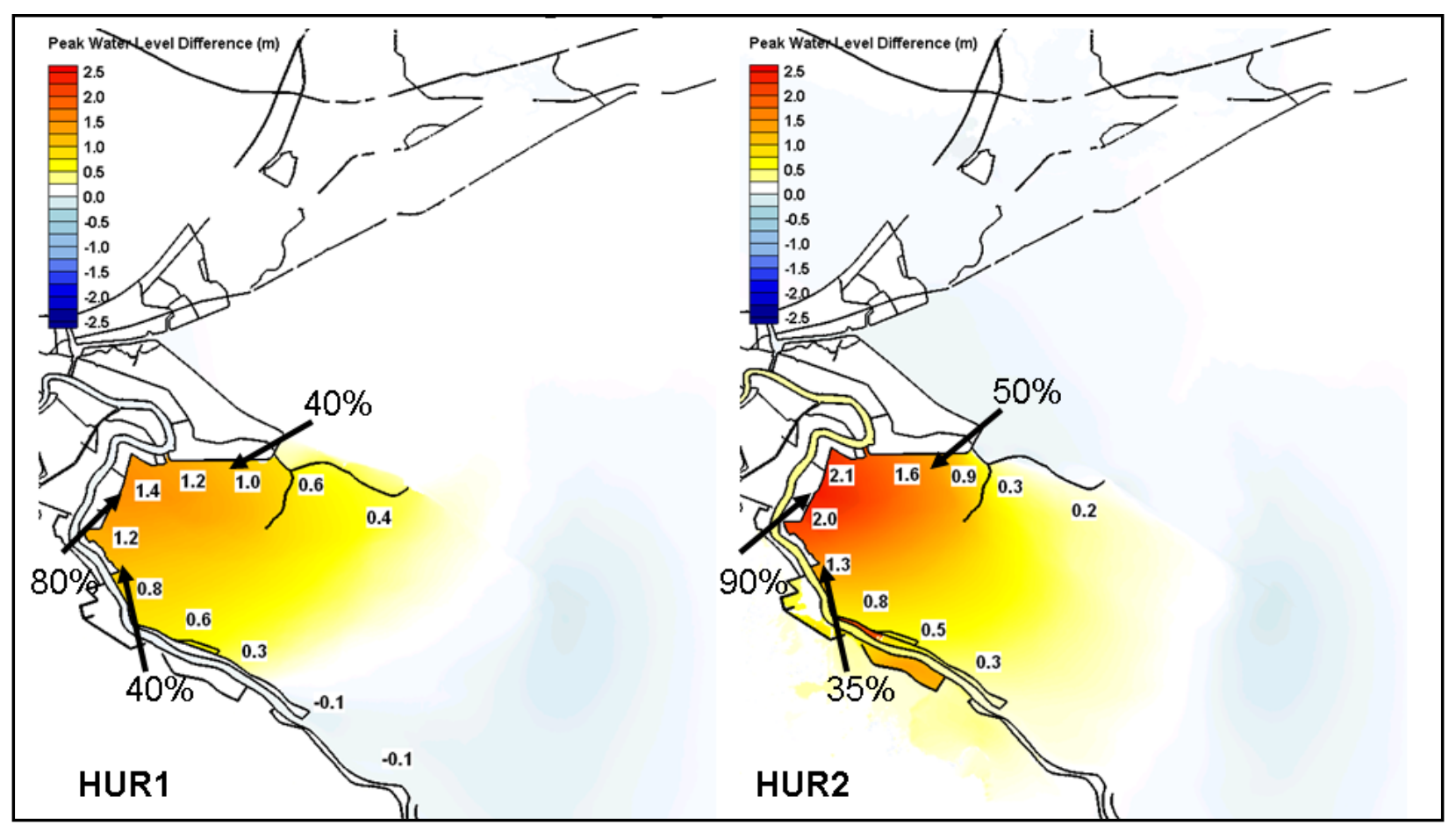

Figure 9. Difference in peak surge level between the degraded and base conditions. 


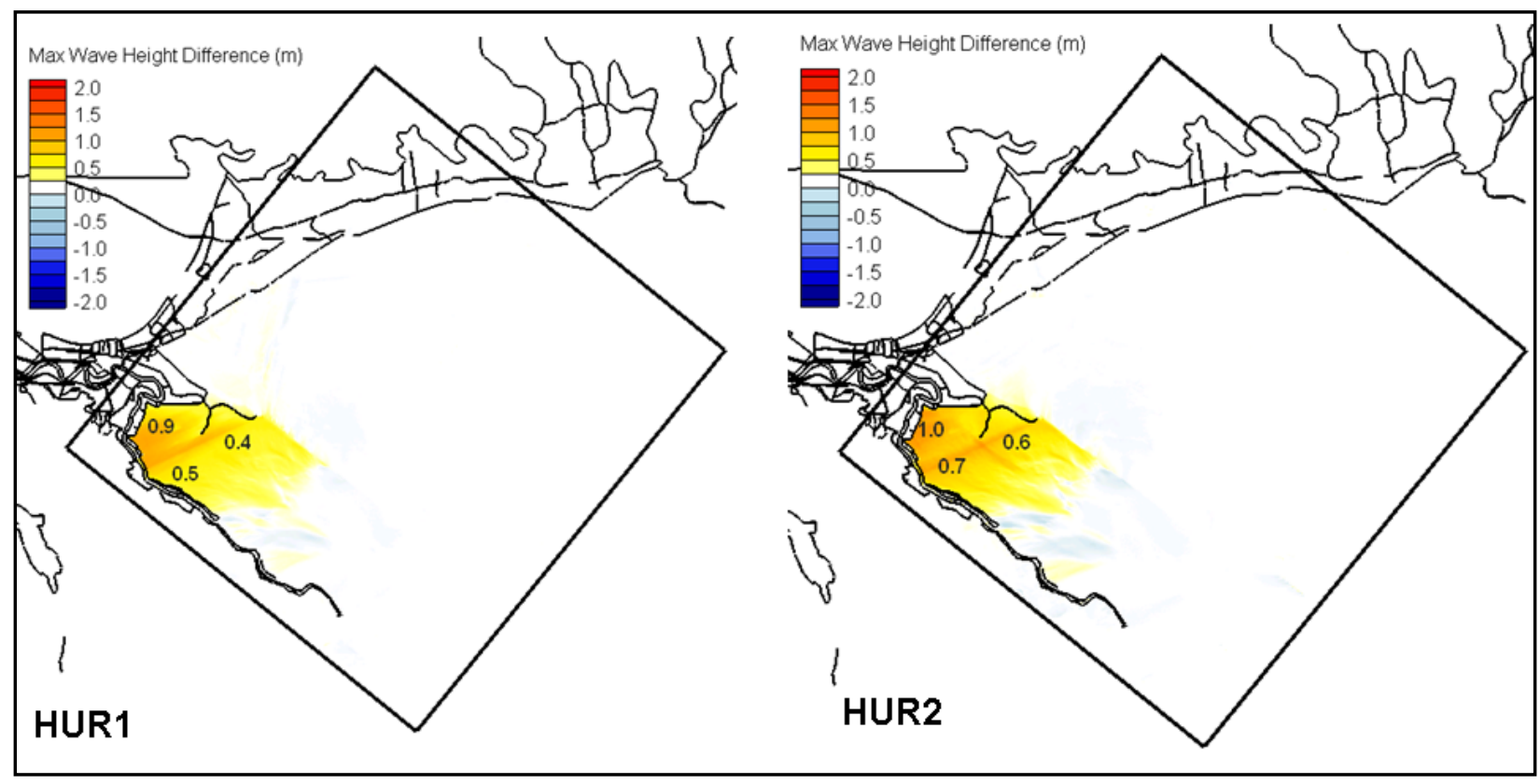

Figure 10. Difference in maximum wave height between the restored and base conditions.

SUMMARY: The purpose of this analysis was to apply numerical models to assess the potential of marsh for reducing storm surge and waves for a moderate and severe hurricane. The impact of landscape features such as wetlands on surge propagation is a relatively new application for surge and wave models and an area of active research that suffers from a lack of quality data. The analysis provides valuable information on trends and relative performance but should not be taken as a definitive quantitative assessment of surge and wave reduction. The set of hypothetical hurricanes considered here is quite small; and there are many other possible combinations of hurricane track, intensity, size, and forward speed. Different combinations of hurricane parameters are expected to change the effects of landscape restoration/degradation on storm surge and waves in different ways. Results indicate that coastal marsh does have the potential to reduce surge and wave magnitudes. Restoration and degradation of marsh resulted in a decrease (for restoration cases) and an increase (for degradation cases) in surge elevations and wave heights for hurricanes of both moderate and severe intensity. The magnitude of change was generally greatest for the more intense storm.

ADDITIONAL INFORMATION: Questions about this CHETN can be addressed to Mr. Ty V. Wamsley (601-634-2099, email: Ty.Wamsley@us.army.mil). This Technical Note should be referenced as follows:

Wamsley, T. V., M. A. Cialone, J. Westerink, and J. M. Smith. 2009. Numerical modeling system to simulate influence of marsh restoration and degradation on storm surge and waves. Coastal and Hydraulics Engineering Technical Note ERDC/CHL CHETN-I-77, U.S. Army Engineer Research and Development Center, Vicksburg, MS. http://chl.wes.army.mil/library/publications/chetn/ 
ACKNOWLEDGEMENT: This work was performed as part of a study supported by the U.S. Army Engineer District, New Orleans, with additional support provided by the Louisiana Coastal Area Science and Technology Program.

\section{REFERENCES:}

Bunya, S., J. J. Westerink, J. C. Dietrich, H. J. Westerink, L. G. Westerink, J. Atkinson, B. Ebersole, J. M. Smith, D. Resio, R. Jensen, M. A. Cialone, R. Luettich, C. Dawson, H. J. Roberts, and J. Ratcliff. 2009. A high resolution coupled riverine flow, tide, wind, wind wave and storm surge model for southern Louisiana and Mississippi: Part I - Model development and validation. Accepted by Monthly Weather Rev.

Federal Emergency Management Agency (FEMA). http://www.fema.gov/hazus/hz_index.shtm.

Komen, G. J., L. Cavaleri, M. Donelan, K. Hasselmann, S. Hasselmann, and P. A. E. M. Janssen. 1994. Dynamics and modelling of ocean waves. Cambridge, UK: Cambridge University Press. 560 pages.

Luettich, R. A., and J. J. Westerink. 2004. Formulation and Numerical Implementation of the 2D/3D ADCIRC Finite Element Model Version 44.XX, web publication, http://adcirc.org/adcirc_theory_2004_12_08.pdf

Luettich, R. A., J. J. Westerink, and N. W. Scheffner. 1992. ADCIRC: An advanced three-dimensional circulation model for shelves, coasts, and estuaries; Report 1, Theory and methodology of ADCIRC-2DDI and ADCIRC3DL, Technical Report DRP-92-6, Vicksburg, MS: U.S. Army Engineer Waterways Experiment Station.

Smith, J. M. 2007. Full-plane STWAVE with bottom friction: II. Model overview. http://chl.erdc.usace.army.mil/ library/publications/chetn-i-75.pdf ERDC TN-SWWRP-07-5. Vicksburg, MS: U.S. Army Engineer Research and Development Center.

Smith, J. M., A. R. Sherlock, and D. T. Resio. 2001. STWAVE: Steady-State spectral Wave Model User's manual for STWAVE, Version 3.0, ERDC/CHL SR-01-1. Vicksburg, MS: U.S. Army Engineer Research and Development Center.

Thompson, E. F., and V. J. Cardone. 1996. Practical modeling of hurricane surface wind fields. J. Waterway, Port, Coastal Engr., 122, 4, 195-205.

Wamsley, T. V., M. C. Cialone, J. M. Smith, B. A. Ebersole, and A. S. Grzegorzewski. 2009. Influence of landscape restoration and degradation on storm surge and waves in southern Louisiana. accepted by Journal of Natural Hazards.

Westerink, J. J., C. A. Blain, R. A. Luettich, Jr., and N. W. Scheffner. 1994. ADCIRC: An advanced three-dimensional circulation model for shelves coasts and estuaries, Report 2: Users manual for ADCIRC-2DDI, Dredging Research Program Technical Report DRP-92-6. Vicksburg, MS: U.S. Army Engineer Waterways Experiment Station.

Westerink, J. J., R. A. Luettich, J. C. Feyen, J. H. Atkinson, C. Dawson, H. J. Roberts, M. D. Powell, J. D. Dunion, E. J. Kubatko, and H. Pourtaheri. 2008. A basin to channel scale unstructured grid hurricane storm surge model applied to southern Louisiana. Monthly Weather Rev 136, 3, 833-864.

NOTE: The contents of this technical note are not to be used for advertising, publication, or promotional purposes. Citation of trade names does not constitute an official endorsement or approval of the use of such products. 